Research article

Open Access

\title{
Identification of novel genetic susceptibility loci for Behçet's disease using a genome-wide association study
} Yiping Fei1,2, Ryan Webb ${ }^{2,3}$, Beth L Cobb ${ }^{2,4}$, Haner Direskeneli5, Güher Saruhan-Direskeneli6 and Amr H Sawalha $1,2,7$

\author{
${ }_{1}^{1}$ Department of Medicine, University of Oklahoma Health Sciences Center, 825 NE 13th Street, Oklahoma City, OK 73104, USA \\ ${ }^{2}$ Arthritis \& Immunology Program, Oklahoma Medical Research Foundation, 825 NE 13th Street, Oklahoma City, OK 73104, USA \\ ${ }^{3}$ College of Public Health, University of Oklahoma Health Sciences Center, 825 NE 13th Street, Oklahoma City, OK 73104, USA \\ 4JK Autoimmunity Inc., 755 Research Parkway, Oklahoma City, OK 73104, USA \\ ${ }^{5}$ Division of Rheumatology, Department of Internal Medicine, Marmara University Medical School, Tophanelioglu Cad. 13/15, 34662, Uskudar, \\ Istanbul, Turkey \\ ${ }^{6}$ Department of Physiology, Istanbul Faculty of Medicine, Istanbul University, Capa 34093, Istanbul, Turkey \\ 7US Department of Veterans Affairs Medical Center, 921 NE 13th Street, Oklahoma City, OK 73104, USA
}

Corresponding author: Amr H Sawalha, amr-sawalha@ouhsc.edu

Received: 31 Mar 2009 Revisions requested: 28 Apr 2009 Revisions received: 3 May 2009 Accepted: 14 May 2009 Published: 14 May 2009

Arthritis Research \& Therapy 2009, 11:R66 (doi:10.1186/ar2695)

This article is online at: http://arthritis-research.com/content/11/3/R66

(c) 2009 Fei et al.; licensee BioMed Central Ltd.

This is an open access article distributed under the terms of the Creative Commons Attribution License (http://creativecommons.org/licenses/by/2.0), which permits unrestricted use, distribution, and reproduction in any medium, provided the original work is properly cited.

\begin{abstract}
Introduction Behçet's disease is a chronic systemic inflammatory disease that remains incompletely understood. Herein, we perform the first genome-wide association study in Behçet's disease.

Methods Using DNA pooling technology and the Affymetrix $500 \mathrm{~K}$ arrays, we identified possible candidate gene associations with Behçet's disease in a cohort of 152 Behçet's disease patients and 172 healthy ethnically matched controls. Genetic loci that were identified in the pooling study were genotyped in patients and controls using TaqMan genotyping technology.

Results We identified genetic associations between Behçet's disease and single-nucleotide polymorphisms (SNPs) in

KIAA1529, CPVL, LOC100129342, UBASH3B, and UBAC2 (odds ratio $=2.04,2.26,1.84,1.71$, and 1.61 , respectively; $P$ value $=4.2 \times 10^{-5}, 1.0 \times 10^{-4}, 3.0 \times 10^{-4}, 1.5 \times 10^{-3}$, and $5.8 \times$ $10^{-3}$, respectively). Among the associated SNPs, the Behçet's disease-risk allele in rs 2061634 leads to substitution of serine to cysteine at amino acid position 995 (S995C) in the KIAA1529 protein.

Conclusions Using an unbiased whole-genome genetic association approach, we identified novel candidate genetic loci that are associated with increased susceptibility for Behçet's disease. These findings will help to better understand the pathogenesis of Behçet's disease and identify novel targets for therapeutic intervention.
\end{abstract}

\section{Introduction}

Behçet's disease is a chronic relapsing systemic inflammatory disease characterized by the presence of oro-genital ulcers, cutaneous manifestations, and uveitis. The disease can also lead to vascular complications such as arterial and venous thrombosis, central nervous system vasculitis, arthritis, and gastrointestinal involvement [1]. The etiology of Behçet's disease is not fully understood. Therefore, treatment remains insufficient and relies on non-specific immunosuppressive medications, with significant side effects. Evidence for a genetic contribution to the pathogenesis of the disease comes from strong familial aggregation, the strong predominance in patients with Mediterranean or Asian ancestry, and the confirmed association with HLA-B51 in several ethnic groups [24].

It is estimated that the association with HLA-B51 in Behcet's disease accounts for only $\sim 20 \%$ of the relative risk in siblings 
of affected individuals [1]. This suggests that other genetic elements outside the HLA region carry risk for developing Behçet's disease. Indeed, a genetic linkage study in a cohort of Behçet's disease multiplex families identified evidence for linkage $(P \leq 0.05)$ on 16 chromosomal regions: $1 p 36,4 p 15$, $5 q 12,5 q 23,6 p 22-24,6 q 16,6 q 25-26,7 p 21,10 q 24,12 p 12-$ $13,12 q 13,16 q 12,16 q 21-23,17 p 13,20 q 12-13$, and Xq2628 [5]. Genetic association studies performed via genotyping single-nucleotide polymorphisms (SNPs) in candidate genes have been performed. These revealed genetic associations with several genes, including IRF1 (interferon regulatory factor 1) [6], TNF (tumor necrosis factor) [7,8], and PTPN22 (protein tyrosine phosphatase, non-receptor type 22) [9].

Despite efforts to discover the genetic contribution to the disease etiology, with the exception of the strong association in the HLA region, other genetic associations are largely unconfirmed. We hypothesize that novel genetic loci for Behçet's disease will be identified using an unbiased genome-wide association approach. Herein, we used a DNA pooling technology to perform the first genome-wide association study in Behçet's disease. We identify five novel genetic loci that are associated with the susceptibility to develop Behçet's disease in a cohort of Turkish Behçet's disease patients and controls.

\section{Materials and methods Patients and controls}

We studied a cohort of Behçet's disease patients and controls recruited at Marmara University Medical School, Istanbul, Turkey. Our cohort consisted of 152 Behçet's disease patients and 172 ethnically matched normal healthy controls. All patients fulfilled the 1990 International Study Group classification criteria for Behçet's disease [10]. DNA was extracted from peripheral blood mononuclear cells using standard techniques. All protocols were approved by the institutional review boards or the research ethics committees at Marmara University, the University of Oklahoma Health Sciences Center, and the Oklahoma Medical Research Foundation. All patients provided written informed consent.

\section{DNA pooling studies}

For the initial discovery phase of novel genetic associations, we used a DNA pooling genotyping methodology. DNA pools were generated from cases (five pools) and controls (five pools). DNA samples were first run on a $0.8 \%$ agarose gel to examine the quality of DNA (high molecular weight) and absence of RNA contamination. The DNA quality and quantity were then determined using a NanoDrop ${ }^{\circledR}$ spectrophotometer (NanoDrop Technologies, Inc., now part of Thermo Fisher Scientific Inc., Waltham, MA, USA). Three hundred twenty-two out of 324 DNA samples had a 260/280 ratio between 1.65 and 2.0 and a 260/230 ratio between 1.0 and 2.2 and were used for the pooling experiment. Samples were then serially diluted to a concentration of 17 to $23 \mathrm{ng} / \mu \mathrm{L}$. Following the dilution, each DNA sample was read twice on the NanoDrop and an average was used to determine the concentration. The number of samples in each pool dictated the amount each sample contributes to the pool. The final volume of each pool was $46.5 \mu \mathrm{L}$. This represents a pool for each of the restriction enzymes used (15.5 $\mu \mathrm{L}$ each) and a test pool (15.5 $\mu \mathrm{L})$. The final amount of total genomic DNA in each pool was $250 \mathrm{ng}$. After the pools were generated, the exact protocol developed by Affymetrix (Santa Clara, CA, USA) for a single DNA sample was followed. This included digestion with the appropriate restriction enzyme, ligation of linkers, amplification of targeted DNA, purification of amplified DNA, labeling, hybridization, and scanning. The Affymetrix GeneChip ${ }^{\circledR}$ Human Mapping $500 \mathrm{~K}$ Array was used. Scanning and analysis were performed using GTYPE GeneChip Genotyping Analysis Software version 4.0.0.22 and GCOS GeneChip Operating Software version 1.4.0.036. The GTYPE GeneChip Genotyping Analysis software generates the cel file that contains the signal intensity information in which allele frequencies were determined using software developed in-house by personnel at JKA Genomics (Oklahoma City, OK, USA). GeneChip Genotyping 4.0 software output was used for relative quality control assessment of detection rates $(>98.5 \%)$ and allele distributions $(<10 \%$ difference between pools).

\section{Genotyping}

Candidate genes discovered in our pooling experiment were subsequently genotyped in patients with Behçet's disease and controls using a case-control genetic association approach and the TaqMan SNP Genotyping Assays (Applied Biosystems, Foster City, CA, USA). Allele frequencies and odds ratios (ORs) were determined. The Pearson chi-square values and $P$ values were calculated using Haploview 4.1 [11]. Hardy-Weinberg equilibrium (HWE) $P$ value measures the difference between the observed genotype frequency and the expected genotype frequency based on the observed allele frequency and was determined to examine the randomness of mating and lack of relatedness in our study population. Permutation $P$ values for the allele frequency difference were calculated to correct for multiple testing using Haploview 4.1 [11].

\section{Results}

We studied a cohort of 152 Behçet's disease patients and 172 ethnically matched controls. Our patient groups included $81(53.3 \%)$ men and 71 (46.7\%) women. The control group included 79 (45.9\%) men and 93 (54.1\%) women. The average age of patients at the time of enrollment was $36.4 \pm 11.7$ years (mean \pm standard deviation, SD), and the average age for control participants was $34.2 \pm 11.4$ years (mean \pm SD). There was no significant difference in age between patients and controls $(P>0.05)$. The clinical characteristics of our Behçet's patients included in this study are summarized in Table 1.

The genome-wide scanning included pooled DNA from 152 Behçet's disease patients and 170 controls (2 DNA samples 
Table 1

\begin{tabular}{lc} 
Clinical characteristics of the Behçet's disease cohort studied \\
\hline & Number (percentage) \\
\hline Gender & $81(53.3 \%)$ \\
Males & $71(46.7 \%)$ \\
Females & \\
Clinical manifestations & $152(100 \%)$ \\
Oral ulcers & $115(75.7 \%)$ \\
Genital ulcers & $59(38.8 \%)$ \\
Eye disease & $146(96.1 \%)$ \\
Cutaneous involvement & $4(2.6 \%)$ \\
Gastrointestinal involvement & $79(52 \%)$ \\
Arthritis/arthralgia & $11(7.2 \%)$ \\
Neurological involvement & $44(29 \%)$ \\
Vascular involvement &
\end{tabular}

A total of 152 patients were included in this study. from controls did not pass DNA quality measures and were excluded from the pooling experiment). Genes with at least one SNP with an association $P$ value of less than $1 \times 10^{-5}$ or at least 2 SNPs with an association $P$ value of less than $1 \times$ $10^{-4}$ were identified as possible candidate genes for Behçet's disease and were selected for individual case-control genotyping.

We have identified 10 possible candidate genes based on the unbiased genome-wide pooling association study. Individual case-control genotyping using TaqMan SNP Genotyping Assays confirmed the genetic association between SNPs in five genes that we identify as novel genetic susceptibility loci for Behçet's disease. All SNPs had an HWE $P$ value of greater than 0.05 (Table 2). Genotyping success rate was at least $96 \%$ in the SNPs genotyped, with the exception of the SNP rs4949332, which had a genotyping success rate of $90 \%$.

Among the polymorphisms studied, the SNP rs2061634 located within the gene KIAA1529 on chromosome 9q22 showed the strongest association with Behçet's disease in our cohort. Consequently, we propose the name 'Behçet's dis-

Table 2

Genetic association between candidate single-nucleotide polymorphisms identified using DNA pooling in a cohort of Behçet's disease patients and controls

\begin{tabular}{|c|c|c|c|c|c|c|c|c|}
\hline \multirow[t]{2}{*}{ SNP (location) } & \multirow[t]{2}{*}{ Gene } & \multirow{2}{*}{$\begin{array}{l}\text { Associated } \\
\text { allele }\end{array}$} & \multicolumn{2}{|c|}{ Associated allele frequency } & \multirow[t]{2}{*}{ OR $(95 \% \mathrm{Cl})$} & \multirow[t]{2}{*}{$P$ value } & \multirow{2}{*}{$\begin{array}{l}\text { Permutation } P \\
\text { value }\end{array}$} & \multirow[t]{2}{*}{ HWE $P$ value } \\
\hline & & & $\begin{array}{l}\text { Cases } \\
\mathrm{n}(\%)\end{array}$ & $\begin{array}{c}\text { Controls } \\
\mathrm{n}(\%)\end{array}$ & & & & \\
\hline $\begin{array}{l}\text { rs11206377 } \\
\text { (1p34) }\end{array}$ & LOC100129342 & $\mathrm{G}$ & $189(66.1)$ & $149(51.4)$ & $\begin{array}{c}1.84 \\
(1.32-2.58)\end{array}$ & $3.0 \times 10^{-4}$ & 0.0036 & 0.89 \\
\hline $\begin{array}{l}\text { rs12112050 } \\
(7 p 15)\end{array}$ & CREB5 & $\mathrm{T}$ & $202(67.8)$ & $187(63.2)$ & $\begin{array}{c}1.23 \\
(0.87-1.72)\end{array}$ & 0.24 & 0.93 & 0.75 \\
\hline $\begin{array}{l}\text { rs2061634 } \\
\text { (9q22) }\end{array}$ & KIAA1529 & $\mathrm{G}$ & $128(42.7)$ & $79(26.7)$ & $\begin{array}{c}2.04 \\
(1.45-2.88)\end{array}$ & $4.2 \times 10^{-5}$ & 0.0002 & 0.35 \\
\hline $\begin{array}{l}\text { rs2875984 } \\
(8 q 12)\end{array}$ & CHD7 & $\mathrm{T}$ & $61(20.3)$ & $54(18.6)$ & $\begin{array}{c}1.12 \\
(0.74-1.68)\end{array}$ & 0.60 & 1 & 0.87 \\
\hline $\begin{array}{l}\text { rs317711 } \\
\text { (7p15-p14) }\end{array}$ & $C P V L$ & $\mathrm{C}$ & $76(25.5)$ & $39(13.2)$ & $\begin{array}{c}2.26 \\
(1.47-3.45)\end{array}$ & $1.0 \times 10^{-4}$ & 0.0011 & 0.20 \\
\hline $\begin{array}{l}\text { rs4936742 } \\
\text { (11q24) }\end{array}$ & UBASH3B & $\mathrm{T}$ & $161(56.7)$ & $125(43.4)$ & $\begin{array}{c}1.71 \\
(1.23-2.38)\end{array}$ & $1.5 \times 10^{-3}$ & 0.0195 & 0.84 \\
\hline $\begin{array}{l}\text { rs4949332 } \\
\text { (1p35) }\end{array}$ & PUM1 & $\mathrm{C}$ & $162(60.9)$ & $143(53.0)$ & $\begin{array}{c}2.38 \\
(0.98-1.95)\end{array}$ & 0.064 & 0.50 & 0.83 \\
\hline $\begin{array}{l}\text { rs546550 } \\
(1 p 22-p 21)\end{array}$ & $A B C A 4$ & A & $246(84.8)$ & $230(78.8)$ & $\begin{array}{c}1.51 \\
(0.98-2.31)\end{array}$ & 0.058 & 0.47 & 0.13 \\
\hline $\begin{array}{l}\text { rs6798232 } \\
(3 q 23)\end{array}$ & PLS1 & G & $139(46.3)$ & $125(42.8)$ & $\begin{array}{c}1.15 \\
(0.83-1.60)\end{array}$ & 0.39 & 0.99 & 0.68 \\
\hline $\begin{array}{l}\text { rs9513584 } \\
(13 q 32)\end{array}$ & UBAC2 & $\mathrm{G}$ & $128(44.4)$ & 95 (33.2) & $\begin{array}{c}1.61 \\
(1.15-2.26)\end{array}$ & $5.8 \times 10^{-3}$ & 0.064 & 0.94 \\
\hline
\end{tabular}

Genotyping was performed using the TaqMan SNP Genotyping Assays in the 10 candidate single-nucleotide polymorphisms (SNPs) identified. ABCA4, ATP-binding cassette, sub-family A (ABC1), member 4; CHD7, chromodomain helicase DNA binding protein 7; Cl, confidence interval; CREB5, cAMP responsive element binding protein 5; HWE, Hardy-Weinberg equilibrium; LL, lower limit; OR, odds ratio; PLS1, plastin 1; PUM1, pumilio homolog 1; UL, upper limit. 
ease-associated gene $1^{\prime}$ (BDAG1) as a synonym for $K I A A 1529$. The frequency of rs2061634 risk allele $(\mathrm{G})$ was $42.7 \%$ in Behçet's disease cases compared with $26.7 \%$ in controls $\left(\mathrm{OR}=2.04, P=4.2 \times 10^{-5}\right)$ (Table 2). The diseaserisk allele in rs2061634 leads to a substitution of serine to cysteine at amino acid position 995 (S995C) in the KIAA1529 protein.

The SNP rs317711 located within the gene CPVL (carboxypeptidase, vitellogenic-like) on chromosome $7 \mathrm{p} 15$ had a risk allele frequency $(\mathrm{C})$ of $25.5 \%$ in cases compared with $13.2 \%$ in controls ( $\mathrm{OR}=2.26, P=1.0 \times 10^{-4}$ ). Allele $\mathrm{G}$ in rs11206377 located within the gene LOC100129342 on chromosome 1p34 had a frequency of $66.1 \%$ in cases and $51.4 \%$ in controls $\left(\mathrm{OR}=1.84, P=3.0 \times 10^{-4}\right)$. The SNPs rs9513584 and rs4936742 located within the genes UBAC2 (ubiquitin-associated domain [UBA] containing 2) and $U B A S H 3 B$ (ubiquitin associated and $\mathrm{SH} 3$ domain containing, B) were also associated with Behçet's disease with $P$ values of $5.8 \times 10^{-3}$ and $1.5 \times 10^{-3}$, respectively (Table 2 ). However, the association between rs9513584 within UBAC2 and
Behçet's disease is not significant after correction for multiple testing.

We next determined the genotype frequency differences between patients with Behçet's disease compared with controls. The presence of the homozygous risk genotype was significantly more frequent in patients than controls in all five of the SNPs that are associated with Behçet's disease in our study (Table 3).

A subset analysis was performed to examine the difference in allele frequencies in clinical subsets of Behçet's disease compared with normal controls (Table 4). Interpreting these data is limited by the small number of patients studied. However, the data suggest that the risk allele in rs4936742 is more common in patients with eye involvement and with vascular involvement, suggesting that the disease-associated polymorphism in UBASH3B might predispose to eye and vascular complications in patients with Behçet's disease. Interestingly, the risk allele in rs2061634 (KIAA1529) is more common in patients without eye or vascular involvement (Table 4).

Table 3

Genotype frequencies of the Behçet's disease-associated single-nucleotide polymorphisms identified in this study

\begin{tabular}{|c|c|c|c|c|c|}
\hline \multirow[b]{2}{*}{ SNP } & \multirow[b]{2}{*}{ Genotype } & \multicolumn{2}{|c|}{ Number } & \multirow[b]{2}{*}{ OR (95\% Cl) } & \multirow[b]{2}{*}{$P$ value } \\
\hline & & Cases & Controls & & \\
\hline \multirow[t]{3}{*}{ rs11206377 } & GG & 62 & 36 & $2.29(1.39-3.78)$ & $0.0011(G G$ versus $A G+A A)$ \\
\hline & AG & 66 & 77 & & \\
\hline & AA & 16 & 32 & & \\
\hline \multirow[t]{3}{*}{ rs2061634 } & GG & 32 & 8 & $4.79(2.13-10.77)$ & 0.000047 (GG versus $C G+C C)$ \\
\hline & CG & 66 & 66 & & \\
\hline & $\mathrm{CC}$ & 56 & 80 & & \\
\hline \multirow[t]{3}{*}{ rs317711 } & $\mathrm{CC}$ & 12 & 3 & $4.23(1.17-15.32)$ & 0.018 (CC versus $\mathrm{GC}+\mathrm{GG})$ \\
\hline & GC & 53 & 34 & & \\
\hline & GG & 85 & 112 & & \\
\hline \multirow[t]{3}{*}{ rs4936742 } & TT & 47 & 23 & $2.60(1.48-4.59)$ & 0.00076 (TT versus $\mathrm{CT}+\mathrm{CC})$ \\
\hline & СT & 67 & 79 & & \\
\hline & $\mathrm{CC}$ & 28 & 42 & & \\
\hline \multirow[t]{3}{*}{ rs9513584 } & GG & 32 & 14 & $2.69(1.37-5.29)$ & $0.0033(\mathrm{GG}$ versus $\mathrm{AG}+\mathrm{AA})$ \\
\hline & $A G$ & 66 & 70 & & \\
\hline & $\mathrm{AA}$ & 47 & 63 & & \\
\hline
\end{tabular}

Odds ratios (ORs) and $P$ values were calculated for the frequency of the homozygous-risk genotype in patients compared with controls. Cl, confidence interval; SNP, single-nucleotide polymorphism. 
Table 4

Subset analysis showing genetic association between clinical subsets of patients with Behçet's disease compared with normal healthy controls

\begin{tabular}{|c|c|c|c|c|c|c|}
\hline \multirow[t]{2}{*}{ Clinical subset } & \multirow[t]{2}{*}{ SNP } & \multirow[t]{2}{*}{ Associated allele } & \multirow[t]{2}{*}{ OR } & \multicolumn{2}{|c|}{$95 \%$ confidence interval } & \multirow[t]{2}{*}{$P$ value } \\
\hline & & & & LL & UL & \\
\hline \multirow[t]{5}{*}{ Eye disease present } & rs11206377 & $\mathrm{G}$ & 1.81 & 1.13 & 2.90 & 0.0125 \\
\hline & rs2061634 & $\mathrm{G}$ & 1.82 & 1.14 & 2.89 & 0.011 \\
\hline & rs317711 & $\mathrm{C}$ & 2.31 & 1.34 & 3.98 & 0.0023 \\
\hline & rs4936742 & $\mathrm{T}$ & 2.17 & 1.37 & 3.44 & 0.0008 \\
\hline & rs9513584 & $\mathrm{G}$ & 1.05 & 0.65 & 1.69 & 0.8403 \\
\hline \multirow[t]{5}{*}{ Eye disease absent } & rs11206377 & $\mathrm{G}$ & 1.96 & 1.33 & 2.89 & 0.0007 \\
\hline & rs2061634 & $\mathrm{G}$ & 2.26 & 1.54 & 3.33 & $3.01 \times 10^{-5}$ \\
\hline & rs317711 & C & 2.26 & 1.41 & 3.63 & 0.0006 \\
\hline & rs4936742 & $\mathrm{T}$ & 1.40 & 0.96 & 2.04 & 0.0823 \\
\hline & rs9513584 & $\mathrm{G}$ & 1.97 & 1.34 & 2.88 & 0.0005 \\
\hline \multirow[t]{5}{*}{ Vascular disease present } & rs11206377 & $\mathrm{G}$ & 2.01 & 1.18 & 3.40 & 0.009 \\
\hline & rs2061634 & $\mathrm{G}$ & 1.47 & 0.88 & 2.46 & 0.1385 \\
\hline & rs317711 & $\mathrm{C}$ & 2.20 & 1.21 & 3.99 & 0.0087 \\
\hline & rs4936742 & $\mathrm{T}$ & 2.04 & 1.23 & 3.36 & 0.0049 \\
\hline & rs9513584 & G & 1.74 & 1.05 & 2.86 & 0.0292 \\
\hline \multirow[t]{5}{*}{ Vascular disease absent } & rs11206377 & G & 1.86 & 1.29 & 2.70 & 0.001 \\
\hline & rs2061634 & $\mathrm{G}$ & 2.35 & 1.62 & 3.43 & $6.22 \times 10^{-6}$ \\
\hline & rs317711 & C & 2.25 & 1.42 & 3.57 & 0.0004 \\
\hline & rs4936742 & $\mathrm{T}$ & 1.54 & 1.07 & 2.21 & 0.0209 \\
\hline & rs9513584 & $\mathrm{G}$ & 1.52 & 1.04 & 2.20 & 0.0281 \\
\hline \multirow[t]{5}{*}{ Both eye and vascular disease present } & rs11206377 & $\mathrm{G}$ & 3.11 & 1.29 & 7.47 & 0.0082 \\
\hline & rs2061634 & $\mathrm{G}$ & 1.37 & 0.66 & 2.88 & 0.3987 \\
\hline & rs317711 & $\mathrm{C}$ & 3.29 & 1.52 & 7.12 & 0.0015 \\
\hline & rs4936742 & $\mathrm{T}$ & 2.39 & 1.14 & 5.02 & 0.0184 \\
\hline & rs9513584 & $\mathrm{G}$ & 1.24 & 0.60 & 2.59 & 0.5585 \\
\hline \multirow[t]{5}{*}{ Neither eye nor vascular disease present } & rs11206377 & $\mathrm{G}$ & 2.10 & 1.36 & 3.24 & 0.0007 \\
\hline & rs2061634 & $\mathrm{G}$ & 2.59 & 1.70 & 3.95 & $7.16 \times 10^{-6}$ \\
\hline & rs317711 & $\mathrm{C}$ & 2.50 & 1.51 & 4.14 & 0.0003 \\
\hline & rs4936742 & $\mathrm{T}$ & 1.30 & 0.86 & 1.98 & 0.2123 \\
\hline & rs9513584 & $\mathrm{G}$ & 1.84 & 1.21 & 2.79 & 0.0042 \\
\hline
\end{tabular}

LL, lower limit; OR, odds ratio; SNP, single-nucleotide polymorphism; UL, upper limit. 


\section{Discussion}

Behçet's disease is a chronic relapsing inflammatory disease associated with debilitating clinical consequences. The disease is more frequent in regions along the 'Silk Road'; however, cases have been reported in all ethnic groups. The pathogenesis of Behçet's disease remains incompletely understood. We have performed a genome-wide genetic association study using a cohort of Turkish Behçet's disease patients and controls. We identified novel genetic susceptibility loci for Behçet's disease in KIAA1529, CPVL, $L O C 100129342$, and UBASH3B. A probable association with UBAC2 was also identified.

KIAA1529 and LOC100129342 are located on chromosome $9 q 22$ and 1p34, respectively, and have no known function to date. The association between polymorphisms within KIAA1529 and LOC100129342 with Behçet's disease suggests a potential role for these unknown genes in regulating the immune response. LOC100129342 is located on chromosome 1 p34 close to 1 p36, a susceptibility region previously identified in families with Behçet's disease by genetic linkage studies [5]. It is possible that LOC100129342 explains or contributes to the genetic linkage effect in that region.

The genes $U B A S H 3 B$ and UBAC2 both contain a UBA, suggesting that both gene products are involved in the ubiquitination pathway. Interestingly, a polymorphism in a third ubiquitinrelated gene, SUMO4 (small ubiquitin-like modifier 4), was associated with the risk to develop Behçet's disease in Chinese patients [12]. Ubiquitination reactions are involved in diverse biological functions, including regulating receptor tyrosine kinase signaling by modulating endocytosis and degradation of activated receptors [13]. UBASH3B has been shown to negatively regulate $T$-cell receptor signaling [14]. In mice deficient in both $U B A S H 3 B$ and UBASH3A (both are related proteins with $75 \%$ homology), $T$ cells are hyper-responsive to T-cell receptor stimulation and demonstrate a marked increase in cytokine production. Furthermore, double-knockout mice had increased incidence and severity of experimental autoimmune encephalomyelitis (EAE) compared with wild-type mice [14]. These data suggest that an abnormal ubiquitination pathway might be involved in the pathogenesis of Behçet's disease.

CPVL gene encodes for a carboxypeptidase that belongs to a large group of proteases that cleave a single amino acid from the carboxy terminus of proteins or peptides. CPVL is expressed on human macrophages but not in other types of leukocytes [15]. The exact nature and extent of function of this carboxypeptidase are yet to be determined. A polymorphism in this gene would potentially affect the function of any of the peptides cleaved by this enzyme and therefore could interfere with normal macrophage function or alter innate immune responses.

\section{Conclusions}

We performed a genome-wide association study and identified novel candidate genetic loci that confer increased susceptibility for Behçet's disease. Further work to replicate these findings in independent cohorts, to identify the disease-causing polymorphisms in these loci, and to determine the functional consequences of these polymorphisms will help us to better understand the pathogenesis of Behçet's disease and identify novel therapeutic targets against this disease.

\section{Competing interests}

The authors declare that they have no competing interests.

\section{Authors' contributions}

YF performed the acquisition of data. RW performed the acquisition and analysis of data. BLC performed the analysis of pooling data. HD and GS-D provided DNA samples, made a substantial contribution to the acquisition of data, and critically revised the manuscript. AHS designed the experiments, performed data analysis and interpretation, and wrote the manuscript. All authors read and approved the final manuscript.

\section{Acknowledgements}

This work was made possible by funding from National Institutes of Health (NIH) grant number P20-RR015577 from the National Center for Research Resources, NIH grant number R03Al076729 from the National Institute of Allergy and Infectious Diseases, funding from the University of Oklahoma College of Medicine (to AHS), and support from the Oklahoma City VA and the Oklahoma Medical Research Foundation.

\section{References}

1. Yazici H, Fresko I, Yurdakul S: Behcet's syndrome: disease manifestations, management, and advances in treatment. Nat Clin Pract Rheumatol 2007, 3:148-155.

2. Mizuki N, Ota M, Katsuyama Y, Yabuki K, Ando H, Shiina T, Palimeris GD, Kaklamani E, Ito D, Ohno S, Inoko H: Sequencingbased typing of HLA-B* 51 alleles and the significant association of HLA-B* 5101 and $-B^{*} 5108$ with Behcet's disease in Greek patients. Tissue Antigens 2002, 59:118-121.

3. Benezra D: Primary association of HLA-B51 with Behcet's disease in Ireland. Br J Ophthalmol 1998, 82:715.

4. Mizuki N, Ota M, Katsuyama Y, Yabuki K, Ando H, Shiina T, Nomura $E$, Onari K, Ohno S, Inoko H: HLA-B*51 allele analysis by the PCR-SBT method and a strong association of HLA$B^{\star} 5101$ with Japanese patients with Behcet's disease. Tissue Antigens 2001, 58:181-184.

5. Karasneh J, Gul A, Ollier WE, Silman AJ, Worthington J: Wholegenome screening for susceptibility genes in multicase families with Behcet's disease. Arthritis Rheum 2005, 52:1836-1842.

6. Lee YJ, Kang SW, Song JK, Baek HJ, Choi HJ, Bae YD, Ryu HJ, Lee EY, Lee EB, Song YW: Associations between interferon regulatory factor-1 polymorphisms and Behcet's disease. Hum Immunol 2007, 68:770-778.

7. Akman A, Sallakci N, Coskun M, Bacanli A, Yavuzer U, Alpsoy E, Yegin O: TNF-alpha gene $1031 \mathrm{~T} / \mathrm{C}$ polymorphism in Turkish patients with Behcet's disease. $\mathrm{Br} J$ Dermatol 2006, 155:350-356.

8. Kamoun M, Chelbi H, Houman MH, Lacheb J, Hamzaoui K: Tumor necrosis factor gene polymorphisms in Tunisian patients with Behcet's disease. Hum Immunol 2007, 68:201-205.

9. Baranathan V, Stanford MR, Vaughan RW, Kondeatis E, Graham E, Fortune F, Madanat W, Kanawati C, Ghabra M, Murray PI, Wal- 
lace GR: The association of the PTPN22 620W polymorphism with Behcet's disease. Ann Rheum Dis 2007, 66:1531-1533.

10. Criteria for diagnosis of Behcet's disease. International Study Group for Behcet's Disease. Lancet 1990, 335:1078-1080.

11. Barrett JC, Fry B, Maller J, Daly MJ: Haploview: analysis and visualization of LD and haplotype maps. Bioinformatics 2005, 21:263-265.

12. Hou S, Yang P, Du L, Zhou H, Lin X, Liu X, Kijlstra A: SUMO4 gene polymorphisms in Chinese Han patients with Behcet's disease. Clin Immunol 2008, 129:170-175.

13. Kowanetz K, Crosetto N, Haglund K, Schmidt MH, Heldin $\mathrm{CH}$, Dikic I: Suppressors of T-cell receptor signaling Sts-1 and Sts2 bind to $\mathrm{Cbl}$ and inhibit endocytosis of receptor tyrosine kinases. J Biol Chem 2004, 279:32786-32795.

14. Carpino N, Turner S, Mekala D, Takahashi Y, Zang H, Geiger TL, Doherty P, Ihle JN: Regulation of ZAP-70 activation and TCR signaling by two related proteins, Sts-1 and Sts-2. Immunity 2004, 20:37-46.

15. Mahoney JA, Ntolosi B, DaSilva RP, Gordon S, McKnight AJ: Cloning and characterization of CPVL, a novel serine carboxypeptidase, from human macrophages. Genomics 2001, 72:243-251. 